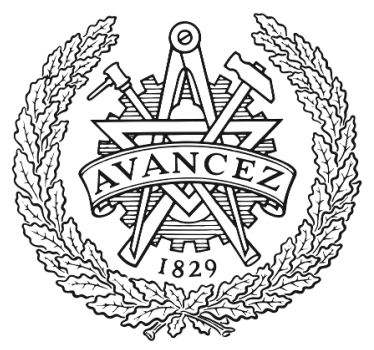

CHALMERS

UNIVERSITY OF TECHNOLOGY

\title{
Reviewing the Role of Sustainability Professionals in Construction
}

Downloaded from: https://research.chalmers.se, 2023-04-26 04:03 UTC

Citation for the original published paper (version of record):

Månsson, S. (2019). Reviewing the Role of Sustainability Professionals in Construction. Emerald

Reach Proceedings Series: 393-399. http://dx.doi.org/10.1108/S2516-285320190000002021

N.B. When citing this work, cite the original published paper. 


\title{
Reviewing the Role of Sustainability Professionals in Construction
}

Reviewing the Role of Sustainability Professionals

\author{
Stina Månsson \\ Technology Management and Economics, Chalmers University of Technology, \\ Gothenburg, Sweden
}

\begin{abstract}
Purpose - This paper aims to explore what is known in the body of literature on sustainability professionals in the architecture, engineering and construction (AEC) industry to support the formulation of research questions for future studies.

Design/Methodology/Approach - This was done through a systematic literature review in Scopus and Web of Science. In the literature search, 22 journal papers were selected to be included in the review because of their relevance to sustainability professionals, professional roles and environmental practices in the AEC industry.

Findings - Key characteristics of the papers such as methodology and theory are mapped, followed by main findings on how the sustainability profession and sustainability professionals' roles are studied within the body of literature. The review shows that the topic of sustainability professionals in the AEC industry is currently under-researched and under-theorised. Specifically, there is a lack of in-depth studies on sustainability professionals' roles and agency.
\end{abstract}

Research Limitations/Implications - By providing an overview of the current literature on sustainability professionals in the AEC industry, it is possible to identify research gaps to formulate research questions for future studies.

Practical Implications - This is important as collaboration between professions, including sustainability professionals, is believed to be the key for a successful shift towards sustainability; furthering the understanding of sustainability professionals' role is, therefore, central.

Originality/Value - This paper is the first systematic literature review on sustainability professionals in the AEC industry.

Keywords Professionalization, Sustainability professionals, Experts, Roles, AEC Industry, Literature review

All papers within this proceedings volume have been peer reviewed by the scientific committee of the 10th Nordic Conference on Construction Economics and Organization (CEO 2019).

\section{Introduction}

Increasing demand on sustainability has led to the emergence of sustainability professionals in the architecture, engineering and construction (AEC) industry who challenge traditional practices and ways of reasoning within the organisation (Hughes and Hughes, 2013). However,

(C) Stina Månsson. Published in the Emerald Reach Proceedings Series. Published by Emerald Publishing Limited. This article is published under the Creative Commons Attribution (CC BY 4.0) licence. Anyone may reproduce, distribute, translate and create derivative works of this article (for both commercial and non-commercial purposes), subject to full attribution to the original publication and authors. The full terms of this licence may be seen at http://creativecommons.org/licences/by/4.0/ legalcode
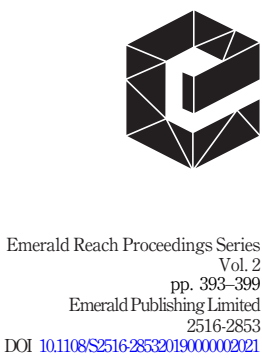
10th Nordic Conference Tallinn even though sustainability professionals are receiving higher influence, organisational aspects such as unclear roles and different time-perspectives between construction projects and the line organisation complicate the work of sustainability professionals (Gluch, 2009, Gluch and Räisänen, 2012). This, in turn, leads to tensions between different professions such as environmental professionals and other built-environment professionals, e.g. site managers.

This gives rise to a dilemma as collaboration between professions including sustainability 2013, Bresnen, 2013). The success of implementing the sustainability agenda is, thus,

dependent on how sustainability professions are received and established within the project oroanisation as well as how traditional roles adapt to this change. Therefore, it is of interest to explore professional roles and professionalization of sustainability professionals in the AEC industry.

Today, there are several papers focusing on the implementation of environmental management systems, environmental assessment tools and project management practices (e.g. Campos et al., 2016, Ortiz et al., 2009, Ferenhof et al., 2014). However, there is less focus on professionalization and professional roles, and currently, there is no systematic literature review on sustainability professionals in the AEC industry. To support the formulation of research questions for future studies, the aim of this study is therefore to explore what is known in the literature on sustainability professionals in the AEC industry.

This is done by reviewing the role of sustainability professionals in the body of literature. The paper is structured as follows; firstly, a brief overview of the concept of professionalization is presented; then, the literature search and selection of literature for the review is described, followed by main findings on how the sustainability profession and sustainability professionals' roles are studied within the body of literature, ending with some suggestions for future research questions.

\section{Professionalization}

In a study by Mieg (2009) on excellence and professionalism of environmental professionals, professionalism is related to the commitment in a profession and the support it holds by its professionals, for example, by the presence of professional roles, norms, standards and educational training. Therefore, professionalization in this study refers to how the sustainability profession is received and established within the organisation and the industry in terms of above-mentioned aspects. In this review, sustainability professionals (or environmental professionals) are people who, in their job description, work with environmental sustainability, i.e. environmental experts, specialists or sustainability managers.

\section{Method}

The review followed the process of a systematic review. The reason for applying a systematic approach is because it provides an overview of the body of literature in a nonbiased way (Bryman and Bell, 2007).

\subsection{Screening process}

The following keywords were decided upon in Scopus; (sustainability OR environmental) AND professional* AND organization* AND roles AND ("construction industry" OR "AEC Industry"). This returned 1,012 articles published in journals from January 2000 up until October 2018. An initial screening of papers was done based on titles in combination with publishing journal. Papers that seemed to address professionalization, professional roles or environmental management in journals related to construction, management or sustainability were selected. In this case, the initial screening returned 100 articles. From 
reading the abstracts of these articles, 57 papers were then selected. The same procedure was then applied in Web of Science, and after reviewing the abstracts and removing those already found in Scopus, three additional articles were added to the list of relevant papers. The reason for doing the literature search in Scopus and Web of Science was to obtain a cross section of the body of literature and to ensure articles of quality.

Two references (Gluch and Bosch-Sijtsema, 2016, Gluch and Räisänen, 2012) were found extra relevant because of their focus on environmental professionals and roles and, thus, used for further reviewing of references and citations for a more exhaustive search. This added 28 papers to the list of relevant papers. In the end, 88 papers were read and 22 papers were selected to be included in the focused literature review because of their relevance to sustainability professionals, professional roles and environmental practices in the AEC industry.

\subsection{Analysis of literature}

The review was synthesised into a database where each paper was mapped across five dimensions: 1. type of study (i.e. research paper, review paper, etc.), 2. focus of study (i.e. aim of study), 3. theory, 4. methodology (i.e. research strategy, research design and methods) and 5. main contribution. The data base then served as basis for further analysis.

\section{Literature review}

Key characteristics of the papers in terms of type of study, methodological approach (research strategy, research design and methods) and theories used are listed in Table 1. Some of the papers apply more than one method and are therefore listed more than once. In general, a qualitative approach is the most common research strategy and the most used research design is the case study design. However, some papers did not specify their research strategy or research design. In the review, papers using theories tend to have a qualitative approach, and they often apply data triangulation, i.e. combination of interviews, observations and document analysis (five papers). Other combinations of methods found in the review are literature review, interviews and questionnaires (two papers), interviews and questionnaires (two papers), interviews and document analysis (one paper) and literature review and questionnaires (one paper).

\subsection{Sustainability professionals in the literature}

Studies vary from briefly mentioning sustainability professionals to in-depth analysis of sustainability professionals' roles and identities. The majority of papers, however, mention

\begin{tabular}{|c|c|c|c|c|c|}
\hline \multirow{2}{*}{$\frac{\text { Type of study }}{\text { Research strategy }}$} & \multirow{2}{*}{$\frac{\text { Research paper (20) }}{\text { Qualitative (12) }}$} & \multirow{2}{*}{$\frac{\text { Review paper (1) }}{\text { Quantitative (4) }}$} & \multicolumn{2}{|l|}{ Conceptual paper (1) } & \\
\hline & & & $\begin{array}{l}\text { Qualitative and } \\
\text { quantitative (4) }\end{array}$ & Unspecified (2) & \\
\hline Research design & Case study (11) & Longitudinal (1) & Cross-sectional (1) & Unspecified (9) & \\
\hline Method & Interviews (16) & $\begin{array}{l}\text { Surveys/ } \\
\text { questionnaires (9) }\end{array}$ & $\begin{array}{l}\text { Document } \\
\text { analysis }(6)\end{array}$ & Field observations (5) & Table 1 \\
\hline Theory & $\begin{array}{l}\text { Other (e.g. literature } \\
\text { Institutional } \\
\text { theory (2) }\end{array}$ & $\begin{array}{l}\text { review) (5) } \\
\text { Practice theory (2) }\end{array}$ & Activity theory (1) & $\begin{array}{l}\text { Social interactionist } \\
\text { theory (1) }\end{array}$ & $\begin{array}{l}\text { Key Characteristics } \\
\text { of Papers Included }\end{array}$ \\
\hline & Sensemaking (1) & $\begin{array}{l}\text { Social learning } \\
\text { theory (1) }\end{array}$ & Systems theory (1) & Translation theory (1) & $\begin{array}{r}\text { in the Review } \\
(\mathrm{N}=22)\end{array}$ \\
\hline
\end{tabular}


10th Nordic Conference Tallinn sustainability professionals very briefly. Instead focus is on improving environmental sustainability through the implementation of environmental tools or green managerial techniques. For example, there are several papers studying the adoption of sustainable construction management practices or LEED (i.e. Hwang and Ng, 2013, Hwang and Tan, 2012, Robichaud and Anantatmula, 2011, Senaratne and Hewamanage, 2015). In these papers, sustainability professionals are referred to as green consultants, LEED consultants or environmental auditors external to the project organisation. Their roles are viewed as necessary for "green" practice but not researched any further. Other papers focus on companies' sustainability strategies (de Paula et al., 2017), or why some procedures are hard to change to more sustainable ones (Palm and Reindl, 2016). However, the role of sustainability professionals in this is not researched.

Then there are papers that focus on the adoption of "green" knowledge. For example, the social learning process of how to design green buildings (Hojem et al., 2014), project managers' adoption of LEED (Kientzel and Kok, 2011) or how environmental assessment methods such as BREEAM influence construction professionals skills and knowledge (Schweber, 2013). However, these papers do not focus on sustainability professionals per se; instead, their focus is on built environment professionals in general and how they develop their professional role to improve their environmental knowledge and skills.

There are some papers that involve professionalization of the sustainability profession in terms of investigating the presence of environmental managers in top management, the recognition of environmental aspects as important issues within the organisation, the knowledge and application of environmental tools, and how environmental work is being valued (e.g. Gluch et al., 2014, Rodriguez et al., 2011, Wallhagen et al., 2016). Other papers study the higher educational training of built professionals and sustainability. For example, how higher education programs may enhance the knowledge and the skills on sustainable development in the built environment (Korkmaz and Singh, 2012, Opoku and Egbu, 2018) and, thereby, increase the importance of the profession.

There are some studies that focus on building professionals as change agents towards sustainable development (Janda and Parag, 2013) or as institutional entrepreneurs (Klein Woolthuis et al., 2013). Then, there are studies in which the role of sustainability professionals is more researched; even if main focus is on environmental management practices, environmental communication or leadership styles (Gluch and Räisänen, 2009, Gluch and Räisänen, 2012, Ludvig et al., 2013, Opoku et al., 2015). In these studies, sustainability professionals are present in both the empirical data and the analysis. Only a few papers study the role of sustainability professionals in-depth. The exceptions are Gluch (2009) and Gluch and Bosch-Sijtsema (2016), which, in contrast to other studies, explore environmental experts' roles, identities and agency in the context of their everyday work.

\section{Conclusions}

The review shows that research on sustainability professionals and the sustainability profession in the AEC industry is currently missing. Specifically, there is a lack of in-depth studies on sustainability professionals' roles and agency. There is also room for theorising the research, which is raised by other scholars as well. For example, Sunding and Ekholm (2015) who argue that construction research would benefit from more influences from the social sciences, Mogendorff (2016) who claims that a performative turn perspective is currently missing when researching expertise in the construction sector and Muzio et al. (2013) who argue that there is much to be gained from research in the intersection of professionalization and institutionalisation. Further, Bresnen (2017) points to the lack of 
institutional theory and its subsets of theories in the construction management research when comparing to business research in general.

Because of this, it would be interesting to study sustainability professionals by exploring professionalization processes, professional roles and practices as mechanisms of institutionalisation towards enhanced sustainability. For example, to better understand how sustainability professionals influence the implementation of the sustainability agenda in terms of changing institutions, practices and norms. As a starting point, four research questions are suggested that may serve as basis for further development to be used in future studies.

(1) What is known in the body of literature on the sustainability profession and professionalization processes for sustainability in other industry segments?

(2) How are sustainability professions and sustainability professionals' roles framed, created, challenged and reformed as organisations are adapting to the sustainability agenda?

(3) What strategies, agency and practices do sustainability professionals employ for institutionalisation towards sustainability?

(4) How do other built environment professionals respond to the introduction of sustainability professionals?

\section{References}

Bresnen, M. (2013), “Advancing a 'new professionalism': professionalization, practice and institutionalization", Building Research \& Information, Vol. 41, No. 6, pp. 735-741.

Bresnen, M. (2017), "Being careful what we wish for? Challenges and opportunities afforded through engagement with business and management research", Construction Management and Economics, Vol. 35, No. 1-2, pp. 24-34.

Bryman, A. and Bell, E. (2007), "Getting started: reviewing the literature", in Business research methods, Oxford University Press, New York, USA, pp. 93-124.

Campos, L.M., Trierweiller, A.C., de Carvalho, D.N., et al. (2016), "Environmental management systems in the construction industry: a review", Environmental Engineering and Management Journal, Vol. 15, No. 2, pp. 453-460.

de Paula, N., Arditi, D. and Melhado, S. (2017), "Managing sustainability efforts in building design, construction, consulting, and facility management firms", Engineering, Construction and Architectural Management, Vol. 24, No. 6, pp. 1,040-1,050.

Ferenhof, H.A., Vignochi, L., Selig, P.M., et al. (2014), "Environmental management systems in small and medium-sized enterprises: an analysis and systematic review", Journal of Cleaner Production, Vol. 74, No., pp. 44-53.

Gluch, P. (2009), "Unfolding roles and identities of professionals in construction projects: exploring the informality of practices", Construction Management and Economics, Vol. 27, No. 10, pp. 959-968.

Gluch, P. and Bosch-Sijtsema, P. (2016), "Conceptualizing environmental expertise through the lens of institutional work", Construction Management and Economics, Vol. 34, No. 7-8, pp. 522-535.

Gluch, P., Gustafsson, M., Thuvander, L., et al. (2014), "Charting corporate greening: environmental management trends in Sweden”, Building Research \& Information, Vol. 42, No. 3, pp. 318-329.

Gluch, P. and Räisänen, C. (2009), "Interactional perspective on environmental communication in construction projects", Building Research \& Information, Vol. 37, No. 2, pp. 164-175.

Gluch, P. and Räisänen, C. (2012), "What tensions obstruct an alignment between project and environmental management practices?", Engineering, Construction and Architectural Management, Vol. 19, No. 2, pp. 127-140.
Reviewing the Role of Sustainability Professionals 
10th Nordic Conference Tallinn
Hojem, T.S.M., Sørensen, K.H. and Lagesen, V.A. (2014), “Designing a 'green’ building: expanding ambitions through social learning”, Building Research \& Information, Vol. 42, No. 5, pp. 591-601.

Hughes, W. and Hughes, C. (2013), "Professionalism and professional institutions in times of change", Building Research \& Information, Vol. 41, No. 1, pp. 28-38.

Hwang, B.-G. and Ng, W.J. (2013), "Project management knowledge and skills for green construction: Overcoming challenges", International Journal of Project Management, Vol. 31, No. 2, pp. 272-284.

Hwang, B.-G. and Tan, J.S. (2012), "Green building project management: obstacles and solutions for sustainable development”, Sustainable Development, Vol. 20, No. 5, pp. 335-349.

Janda, K.B. and Parag, Y. (2013), "A middle-out approach for improving energy performance in buildings", Building Research \& Information, Vol. 41, No. 1, pp. 39-50.

Jaradat, S., Whyte, J. and Luck, R. (2013), "Professionalism in digitally mediated project work”, Building Research \& Information, Vol. 41, No. 1, pp. 51-59.

Kientzel, J. and Kok, G. (2011), "Environmental Assessment Methodologies for Commercial Buildings: An Elicitation Study of U.S. Building Professionals' Beliefs on Leadership in Energy and Environmental Design (LEED)", Sustainability, Vol. 3, No. 12, pp. 2,392-2,412.

Klein Woolthuis, R., Hooimeijer, F., Bossink, B., et al. (2013), "Institutional entrepreneurship in sustainable urban development: Dutch successes as inspiration for transformation”, Journal of Cleaner Production, Vol. 50, No., pp. 91-100.

Korkmaz, S. and Singh, A. (2012), "Impact of Team Characteristics in Learning Sustainable Built Environment Practices", Journal of Professional Issues in Engineering Education and Practice, Vol. 138, No. 4, pp. 289-295.

Ludvig, K., Stenberg, A.-C. and Gluch, P. (2013), "The value of communicative skills for developing an energy strategy", Building Research \& Information, Vol. 41, No. 6, pp. 611-621.

Mieg, H.A. (2009), "Two factors of expertise? Excellence and professionalism of environmental experts", High Ability Studies, Vol. 20, No. 1, pp. 91-115.

Mogendorff, K. (2016), "The building or enactment of expertise in context: what the performative turn in the social sciences may add to expertise research in construction management", Construction Management and Economics, Vol. 34, No. 7-8, pp. 484-491.

Muzio, D., Brock, D.M. and Suddaby, R. (2013), "Professions and institutional change: Towards an institutionalist sociology of the professions", Journal of management studies, Vol. 50, No. 5, pp. 699-721.

Opoku, A., Ahmed, V. and Cruickshank, H. (2015), "Leadership style of sustainability professionals in the UK construction industry”, Built Environment Project and Asset Management, Vol. 5, No. 2, pp. 184-201.

Opoku, A. and Egbu, C. (2018), "Students' Perspectives on the Relevance of Sustainability Literacy in a Postgraduate Built Environment Program”, International Journal of Construction Education and Research, Vol. 14, No. 1, pp. 46-58.

Ortiz, O., Castells, F. and Sonnemann, G. (2009), "Sustainability in the construction industry: A review of recent developments based on LCA", Construction and building materials, Vol. 23, No. 1, pp. 28-39.

Palm, J. and Reindl, K. (2016), "Understanding energy efficiency in Swedish residential building renovation: A practice theory approach", Energy Research \& Social Science, Vol. 11, No., pp. 247-255.

Robichaud, L.B. and Anantatmula, V.S. (2011), "Greening project management practices for sustainable construction", Journal of management in engineering, Vol. 27, No. 1, pp. 48-57.

Rodriguez, G., Alegre, F.J. and Martinez, G. (2011), "Evaluation of environmental management resources (ISO 14001) at civil engineering construction worksites: a case study of the community of Madrid", Journal of Environmental Management, Vol. 92, No. 7, pp. 1,858-1,866. 
Schweber, L. (2013), "The effect of BREEAM on clients and construction professionals", Building Research \& Information, Vol. 41, No. 2, pp. 129-145.

Senaratne, S. and Hewamanage, P.R. (2015), "The role of team leadership in achieving LEED certification in a green building project", Built Environment Project and Asset Management, Vol. 5, No. 2, pp. 170-183.

Sunding, L. and Ekholm, A. (2015), "Applying social sciences to inspire behavioural change in the construction sector: an experimental study", Construction Management and Economics, Vol. 33, No. 9, pp. 695-710.

Reviewing the Role of Sustainability Professionals

Wallhagen, M., Malmqvist, T. and Eriksson, O. (2016), "Professionals' knowledge and use of environmental assessment in an architectural competition", Building Research \& Information, Vol. 45, No. 4, pp. 426-442. 